\title{
ECONOMETRIC MODEL FOR MEASURING THE IMPACT OF THE EDUCATION LEVEL OF THE POPULATION ON THE RECYCLING RATE IN A CIRCULAR ECONOMY
}

\author{
Corina Pelău ${ }^{1 *}$ and Alexandra Cătălina Chinie ${ }^{2}$ \\ ${ }^{122)}$ Bucharest University of Economic Studies, Romania
}

\section{Please cite this article as:}

Pelău, C. and Chinie, A.C., 2018. Econometric Model for Measuring the Impact of the Education Level of the Population on the Recycling Rate in a Circular Economy. Amfiteatru Economic, 20(48), pp. 340-355.

\section{Article History}

Received: 30 December 2017

Revised: 7 March 2018

Accepted: 9 April 2018

\section{DOI: 10.24818/EA/2018/48/340}

\begin{abstract}
Due to the positive effect it has on the environment, while also creating social and economic value, recycling represents a key factor in the realization of a circular economy and of sustainable development. For the implementation of efficient programs, the recycling rate has become a relevant subject to public institutions, but also for the academia, companies and non-profit associations. The objective of this article is to determine the influence of the population's level of education on the recycling rate of waste. The article has a contribution to the scientific literature, by analyzing the correlation between education and the recycling rate in Europe, with living conditions and internet access as control variables. Results of a panel data analysis show that a high percentage of the population with only primary or lower secondary education, influence negatively the recycling rate of waste in an economy, while tertiary education has a positive influence on the level of recycled waste. Therefore, different policies which aim to increase the education level of the population will have an effect on the recycling rate.
\end{abstract}

Key words: recycling, circular economy, sustainable consumption, municipal waste, education level, panel data analysis.

JEL Classification: Q53.

\section{Introduction}

Recycling and waste management continue to represent a relevant and imperative subject, in the attention of governmental organizations worldwide. Adopting an efficient management for the reduction of waste is necessary in order to mitigate negative effects on the environment. Given that recycling activities do not solely produce benefits for the

\footnotetext{
* Corresponding author, Corina Pelău - corinapelau@yahoo.com
} 
environment, as they also create economic and social value (Chen and Tung, 2010; Malinauskaite et al., 2017), recycling represents one of the central measures proposed for the realization of a sustainable development. Waste management is part of the European Union's program for the development of a circular economy (European Union, 2017), including measures such as recycling, using recycled materials and the generation of energy (European Environment Agency, 2016).

Although recycling rates have grown in the last 10 years according to Eurostat data, the recycling rate of municipal waste didn't reach $10 \%$ in some countries in $2016(7.1 \%$ in Malta and $0.3 \%$ in Serbia) (Eurostat, 2017). Recycling rates for packaging waste are higher than recycling rates of municipal waste, although also in this case, a discrepancy between the performance of different countries in Europe can be observed. Thus, while Belgium, the Czech Republic, the Netherlands and Sweden have a recycling rate for packaging waste of over $70 \%$, countries such as Island and Hungary show values of $50.6 \%$, respectively $50.1 \%$ for 2015 (Eurostat, 2017). In this context, identifying the causes that lead to differences of performance regarding waste management and recycling has become an important subject. Analyzing this aspect has two components: defining the performance of recycling activities and identifying the factors that influence performance. Suttibak and Nitivattananon (2008) mention ways of evaluating recycling performance such as participation rate, quantity recovered, diversion rate and utilization rate.

In order to analyze the level of recycling in Europe, we chose to use the recycling rate of municipal waste and tested the impact that education has on this variable, while using internet access, urbanization and living conditions as control variables. The literature review is presented in the first part of the article, with focus on the role of recycling in the circular economy and on other researches presenting the relation between education and the recycling rate. In the second chapter, the methodology is presented. The objectives, the hypotheses, the proposed model and the data collection methods are described. The third chapter contains the actual data analysis, including the statistical analysis of the used data and the measurement of the adequacy of the proposed models with the help of panel data analysis. Based on the results and the analysis, the conclusions and the recommendations have been made.

\section{Literature review}

\subsection{Circular economy and recycling}

Geissdoerfer et al. (2017) define the concept of circular economy as ,a regenerative system in which resource input and waste, emission, and energy leakage are minimized by slowing, closing, and narrowing material and energy loops". The authors consider that this system can be accomplished through "long-lasting design, maintenance, repair, reuse, remanufacturing, refurbishing, and recycling" (Geissdoerfer et al. 2017). The development of the circular economy concept has changed the framework for recycling and waste management, as it was until 1985, when the attention was oriented to the effects of pollution triggered by waste, facilitating the extraction of additional value and the minimization of value loss and destruction (Blomsma and Brennan, 2017).

Reike et al. (2017) state that governments and policy makers have a decisive role in the realization of a circular economy. The European Commission declares that the circular 
economy concept is strongly correlated with its key priorities and proposed an action plan that encompasses targets to „reduce landfilling and to increase preparation for reuse and recycling of key waste streams such as municipal waste and packaging waste" (European Commission, 2015a). The European Commission program for a circular economy includes legislative proposals that set a target of $65 \%$ for the re-use and recycling of municipal waste and $75 \%$ for recycling of packaging waste (European Commission, 2015b; European Commission, 2015c).

\subsection{Factors that influence the recycling process}

Scholars have identified several main factors that influence recycling activities. Infrastructure and the applied governmental policies have an important role in increasing the recycling rate. According to the study of Sidique Joshi and Lupi (2010a), curbside collection and drop-off centers, variable pricing of waste disposal, enactment of ordinances and financing educational programs increase the recycling rate. Other literature contributions show that weight-based billing reduce the volume of waste collected by municipalities, but this fact isn't necessarily correlated with an increase of the recycling rate and might be caused by the reduction of waste produced by households (Dahlen et al., 2007; Dahlen and Lagerkvist, 2010). Dahlen et al. (2007) also underline the positive effect that curbside recycling has on the level of recycling. Municipal waste management can influence the recycling rate through the collection frequency, so that with a lower collection frequency, the recycling rate increases (Abbott, Nandeibam and O'Shea, 2011; Gellynck, Jacobsen and Verhelst, 2011).

Cognitive and non-cognitive factors that influence recycling activities take another important part in the scientific literature. The decision-making process is controlled by the thinking patterns of the person, which are based on their knowledge basis, a set of inference rules and a set of fundamental reference values (Bratianu, 2007). The study of LópezMosquera, Lera-López and Sánchez (2015) discloses that environmental beliefs, interest for environmental information and the level of environmental knowledge have an effect on the rate by which people recycle glass, plastic, and paper waste. Scientific literature on recycling has also underlined the correlation between social norms, perceived behavioral control - how convenient it is to recycle - and the intention to recycle (Chan and Bishop, 2013; Botetzagias, Dima and Malesios, 2015). Consumer behavior in general has a boomerang effect on the pro-environmental behavior, depending on the social norms (Yakobovitch and Grinstein, 2016), the biospheric values (Nguyen, Lobo and Greenland, 2016), the education (Ntona, Arabatzis and Kyriakopoulos, 2015) and the self-efficacy (Lauren et. al, 2016) of the consumers. Also, pressure from the family and peers, along with how convenient it is to recycle and how familiar people are with the recycling infrastructure, influence the number of visits that people make to recycling drop-off sites (Sidique, Lupi and Joshi, 2010b). Beside cognitive knowledge, emotional and spiritual aspects also shape the behavior of people and motivate them (Bratianu, 2013). Positive emotions following nature experiences were associated with more environmental behavior (Junot, Paquet and Martin-Krumm, 2017).

Socio-demographic characteristics that influence the intention to recycle and the recycling rate have also been included in numerous studies (Jones et al., 2010; Sidique, Lupi and Joshi, 2010b; Saphores and Nixon, 2014; Oztekin et al., 2017), although results of different researches on the impact of income, level of education and age are often contradictory (Saphores and Nixon, 2014; Aphale, Thyberg and Tonjes, 2015). 
According to Starr and Nicolson (2015), education (percentage of population with a Bachelor's degree or higher) and age influence the recycling rate significantly: an increase in the median age and of the percentage of population with a Bachelor's degree generate an increase of the recycling rate. Results of the analysis performed by Sidique, Lupi and Joshi (2010b) also reveal a positive correlation with age, but don't identify a statistically significant correlation between the level of education and the number of visits to the drop-off centers. Following their research for the identification of factors that influence the recycling of batteries, Arbués and Villanúa (2016) have found that age and the awareness of an environmental campaign in the previous year are relevant factors for the level of battery recycling.

\section{Research methodology}

\subsection{Hypothesis of the research}

The main objective of this research is the determination of the influence of the education level of the population on the recycling rate of municipal waste in an economy. In order to test the influence of the education in general, we will test the influence of all education levels on the dependent variable, including lifelong learning. Starting from this objective, we have formulated the following hypothesis for the influence of each education level on the recycling rate of waste in an economy:

- H1: The higher percentage of people having only primary and lower secondary education has a negative influence on the recycling rate of waste in an economy;

- H2: The higher percentage of people having upper secondary education or other nontertiary type of education has a positive influence on the recycling rate in an economy;

- H3: The higher percentage of people having graduated a university or a similar tertiary education has a positive influence on the recycling rate in an economy;

- H4: The higher participation of adult population in different forms of lifelong learning programs has a positive influence on the recycling rate in an economy.

All these hypotheses have been formulated starting from the idea, that a higher level of education has a positive influence on the recycling rate, based on the results of Starr and Nicolson (2015), Lopez-Mosquera (2015) and Arbués and Villanúa (2016). People with higher education have broader knowledge for understanding the importance of the recycling process and therefor they have solid motives in order to facilitate and sustain the recycling process. We have also tested the influence of the lifelong learning on the recycling rate.

\subsection{The panel data analysis model}

In order to test the hypotheses presented above, we have developed the following regression model for a panel data analysis:

$X_{\text {recyc,it }}=\beta_{1} X_{\text {EDU0-2,it }}+\beta_{2} X_{\text {EDU3-4,it }}+\beta_{3} X_{\text {EDU5-8,it }}+\beta_{4} X_{\text {LLLearn,it }}+\beta_{5} X_{\text {ONLINE,it }}$

$+\beta_{6} \mathrm{X}_{\mathrm{URBA}, \mathrm{it}}+\beta_{7} \mathrm{X}_{\mathrm{LIVCOND}, \mathrm{it}}+\beta_{8} \mathrm{X}_{\mathrm{LIVCOST}, \mathrm{it}}+\beta_{9} \mathrm{X}_{\mathrm{GDPPC}, \mathrm{it}}+\mathrm{c} 1$

Where:

$\mathrm{i}=$ number of countries included in the analysis;

$\mathrm{t}=$ time unit for the analyzed period. 
The panel regression model has the recycling rate of waste in an economy as a dependent variable. For the measurement of the impact of the education on the recycling rate of waste, we have considered the following independent variables: the percentage of people, who have graduated only from primary and lower secondary education, the percentage of people who have graduated from an upper secondary education, the percentage of tertiary education graduates from the total population and the percentage of people participating in different forms of lifelong education programs. In order to increase the accuracy of the model we have also considered the control variables internet access of households, the degree of urbanization, the living conditions, the living costs and the gross domestic product per capita. A more detailed description of the variables can be found in table 1 . For each of the nine variables, we have defined a coefficient $\beta i, i=1, . ., 9$ and the constant $c_{1}$. The significance of the $\beta$ coefficients and that of the constant $c_{1}$ have been determined with help of the panel data analysis (Baltagi, 2008) in the program Stata 13.0.

\subsection{Data collection}

The dependent variable recycling rate of municipal waste is according to Eurostat one of the indicators which define the circular economy. It describes the percentage of recycled waste from the total waste in that economy. The four independent variables define the level of education of the adult population in the analyzed economy. Three of the independent variables represent the percentage of population with ages between 15-64 years, who have graduated different levels of education as it can be observed in table 1 . The fourth variable represents the percentage of population with ages between 18-64 years, who have participated in different forms of lifelong education.

The following five control variables have also been included in the model: internet access of households as a form of information possibility, the degree of urbanization, living conditions defined as number of locative rooms/ person, living cost and the gross domestic product per capita for the power of the economy. The gross domestic product per capita has been considered in thousand Euros in order to keep the magnitude of the scale. A more detailed description of the variables can be found in table no. 1 .

Table no. 1: Definition of variables

\begin{tabular}{|l|l|l|}
\hline $\begin{array}{c}\text { Variable } \\
\text { code }\end{array}$ & Variable name & \multicolumn{1}{c|}{ Description } \\
\hline Xrecyc & Recycling rate & $\begin{array}{l}\text { This indicator measures the percentage of recycled garbage from the } \\
\text { total produced garbage in the municipalities. It includes recycled } \\
\text { materials, compost and anaerobic material. The value is expressed in } \\
\text { percentage. }\end{array}$ \\
\hline Xedu0-2 & $\begin{array}{l}\text { Education } \\
\text { level 0-2 }\end{array}$ & $\begin{array}{l}\text { Percentage of population with ages between 15-64 years with less } \\
\text { than primary, primary and lower secondary education; education } \\
\text { levels 0-2 according to the ISCED11. }\end{array}$ \\
\hline Xedu3-4 & $\begin{array}{l}\text { Education } \\
\text { level 3-4 }\end{array}$ & $\begin{array}{l}\text { Percentage of population with ages between 15-64 years with upper } \\
\text { secondary and post-secondary non-tertiary education; education } \\
\text { levels 3-4 according to the ISCED11. }\end{array}$ \\
\hline Xedu5-8 & $\begin{array}{l}\text { Education } \\
\text { level 5-8 }\end{array}$ & $\begin{array}{l}\text { Percentage of population with ages between 15-64 years with tertiary } \\
\text { education; education levels 5-8 according to the ISCED11. }\end{array}$ \\
\hline XIllearn & $\begin{array}{l}\text { Life Long } \\
\text { Learning }\end{array}$ & $\begin{array}{l}\text { Participation rate at any form of education of the adult population } \\
\text { with ages between 18-64 years (the participation was considered for } \\
\text { the last 4 weeks); the value is expressed in percentage. }\end{array}$ \\
\hline
\end{tabular}




\begin{tabular}{|l|l|l|}
\hline $\begin{array}{c}\text { Variable } \\
\text { code }\end{array}$ & Variable name & \multicolumn{1}{c|}{ Description } \\
\hline Xonline & $\begin{array}{l}\text { Internet access } \\
\text { of households }\end{array}$ & $\begin{array}{l}\text { Describes the percentage of households, which have access to } \\
\text { internet; the value is expressed in percentage. }\end{array}$ \\
\hline Xurba & Urbanization & Degree of urbanization expressed in percentage. \\
\hline Xlivcond & Living conditions & Average number of rooms/ person for the living space. \\
\hline Xlivcost & Living cost & $\begin{array}{l}\text { The rate of the living cost related to the total income of the } \\
\text { population expressed in percentage. }\end{array}$ \\
\hline Xgdppc & GDPPC & Gross domestic product per capita. \\
\hline
\end{tabular}

The data used for this research have been collected from the Eurostat Database (Eurostat 2017a-g) for the period 2007-2016 for the following 28 countries: Germany, France, United Kingdom, Netherlands, Belgium, Luxembourg, Spain, Italy, Portugal, Greece, Austria, Denmark, Finland, Norway, Sweden, Poland, Czech Republic, Slovakia, Hungary, Romania, Bulgaria, Croatia, Slovenia, Estonia, Latvia, Lithuania, Iceland, and Malta. For the control variables access to internet, degree of urbanization, living conditions and living cost, the data have been available only for the period 2008-2016. Because of the missing data, we have done the analysis based on 237 complete sets of data.

\section{Results and discussions}

\subsection{Statistical analysis of the data}

The statistical variation of the variables and the correlation matrix can be observed in tables no. 2 and no. 3 .

Table no. 2: Statistical variation of variables

\begin{tabular}{|l|c|c|c|c|}
\hline \multicolumn{1}{c|}{ Variable } & Mean & Minimum & Maximum & Standard Deviation \\
\hline Recycling rate & 31.29 & 0.4 & 66.7 & 16.53 \\
\hline Education level 0-2 & 28.42 & 12.4 & 71.4 & 12.31 \\
\hline Education level 3-4 & 47.48 & 16.6 & 72.2 & 12.53 \\
\hline Education level 5-8 & 24.08 & 9.9 & 39.6 & 7.09 \\
\hline Lifelong learning & 17.61 & 6.6 & 38.3 & 7.77 \\
\hline Internet access & 73.44 & 25.0 & 97.0 & 15.39 \\
\hline Urbanization & 41.20 & 13.0 & 89.8 & 14.79 \\
\hline Living conditions & 1.61 & 1.0 & 2.3 & 0.39 \\
\hline Living costs & 10.19 & 1.1 & 40.9 & 5.91 \\
\hline GDPPC & 26.84 & 4.3 & 91.5 & 18.36 \\
\hline
\end{tabular}

Table no. 3: Correlation matrix for the variables

\begin{tabular}{|c|c|c|c|c|c|c|c|c|c|}
\hline Variable & $\begin{array}{c}\text { Edu } \\
\mathbf{0 - 2}\end{array}$ & $\begin{array}{c}\text { Edu } \\
\mathbf{3 - 4}\end{array}$ & $\begin{array}{c}\text { Edu } \\
\mathbf{5 - 8}\end{array}$ & LLL & $\begin{array}{c}\text { Internet } \\
\text { access }\end{array}$ & $\begin{array}{c}\text { Urba- } \\
\text { nization }\end{array}$ & $\begin{array}{c}\text { Liv. } \\
\text { cond. }\end{array}$ & $\begin{array}{c}\text { Liv. } \\
\text { cost }\end{array}$ & $\begin{array}{c}\text { GDP } \\
\text { PC }\end{array}$ \\
\hline Education 0-2 & 1.000 & & & & & & & & \\
\hline Education 3-4 & -0.837 & 1.000 & & & & & & & \\
\hline Education 5-8 & -0.257 & -0.313 & 1.000 & & & & & & \\
\hline Education LLL & -0.077 & -0.263 & 0.601 & 1.000 & & & & & \\
\hline Internet access & -0.167 & -0.202 & 0.648 & 0.698 & 1.000 & & & & \\
\hline Urbanization & 0.539 & -0.536 & 0.010 & -0.019 & 0.024 & 1.000 & & & \\
\hline Living conditions & 0.274 & -0.616 & 0.612 & 0.553 & 0.654 & 0.305 & 1.000 & & \\
\hline Living costs & -0.035 & 0.049 & -0.026 & -0.091 & -0.142 & -0.047 & -0.194 & 1.000 & \\
\hline GDPPC & 0.059 & -0.385 & 0.578 & 0.627 & 0.681 & -0.040 & 0.719 & -0.089 & 1.00 \\
\hline
\end{tabular}


The dependent variable recycling rate has a mean of 13.29 and a standard deviation of 16.53. The minimum value is 0.4 for Romania (2007) and the maximum value is 66.7 for Germany (2015). The variable regarding the education level 0-2 according to ISCED has a mean of 28.42 and a standard deviation of 12.31 . The minimum value of 12.4 is reached by Czech Republic for the years 2014, 2015 and 2016 and the maximum value of 71.4 is reached by Portugal in 2007. The variable regarding the upper secondary education has a mean of 47.48 and s standard deviation of 12.53. The minimum value is 16.6 for Portugal (2007 and 2008) and the maximum value is 72.2 for Czech Republic (2007). The variable university education, level 5-8 according to ISCED has a mean value of 24.08 and a standard deviation of 7.09. The minimum value is 9.9 and it is reached by Romania in 2007 and the maximum value is 39.9 and it is reached by Luxemburg in 2014. For the variable lifelong learning the mean has a value of 17.61 and the standard deviation is 7.77 . The minimum value of 6.6 is reached by Romania in 2015 and the maximum value is 38.3 for Denmark in 2014.

For the control variables, we have the following statistical variation. The variable access to internet has a mean of 73.44 and a standard variation of 15.39 . The minimum value is 25.0 for Bulgaria (2008) and the maximum value of $97.0 \%$ is for Luxemburg (2015 and 2016), for Netherlands (2016) and Norway (2015 and 2016). The degree of urbanization has a mean of 41.20 and a standard deviation of 14.97. The minimum value is 13.0 for Luxemburg (2015) and the maximum value is 89.8 for Malta (2016). The variable living conditions, expressed through the number of rooms/ person for the living space, has a mean of 1.61 and a standard deviation of 0.39 . The minimum value is 1.00 and it is reached by Bulgaria (2008), Latvia (2008-2010), Poland (2008-2011) and Romania (2008-2015). The maximum value 2.3 and it is reached by Belgium (2009, 2011, 2012, 2013 and 2015). The percentage of living costs from the total income has a mean of 10.19 and a standard deviation of 5.91. The minimum value is 1.1 for Malta (2015) and the maximum value is 40.9 for Greece (2015). Regarding the gross domestic product per capita, expressed in thousand Euros, the mean value is 26.84 and the standard deviation is 18.36. The minimum value is 4.3 and it is reached by Bulgaria (2007) and the maximum value is 91.5 and it is reached by Luxemburg in 2015.

The correlation matrix for the independent and the control variables can be observed in table no. 3. It can be observed that for the variables related to education, there is a strong correlation between the education level $0-2$ and the education level 3-4 according to the ISCED standards ( $\mathrm{r}=0.837)$ and a moderate correlation between the education levels 5-8 and the lifelong learning $(\mathrm{r}=0.601)$. For the control variables there is a stronger correlation between the gross domestic product per capita and the living conditions $(r=0.719)$.

\subsection{Results of the panel data analysis with random effect}

In order to test the hypothesis of the model, the panel data analysis with random effect has been applied. The results of the analysis can be observed in table no. 4 and table no. 5 . 
Table no. 4: Panel regression model for the dependent variable recycling rate of municipal waste

\begin{tabular}{|c|c|c|c|c|c|}
\hline \multicolumn{6}{|c|}{ Dependent variable: Recycling rate of waste (\%) } \\
\hline & Model 1 & Model 2 & Model 3 & Model 4 & Model 5 \\
\hline Education level 0-2 & $\begin{array}{l}-0.25 * \\
(-1.93)\end{array}$ & & & & $\begin{array}{l}-9.76^{*} \\
(-1.70)\end{array}$ \\
\hline Education level 3-4 & & $\begin{array}{c}0.08 \\
(0.61)\end{array}$ & & & $\begin{array}{l}-9.54^{*} \\
(-1.66)\end{array}$ \\
\hline Education level 5-8 & & & $\begin{array}{l}0.36^{*} \\
(1.90)\end{array}$ & & $\begin{array}{l}-9.21 \\
(-1.60)\end{array}$ \\
\hline Lifelong learning & & & & $\begin{array}{c}-0.53 * * * \\
(-3.48)\end{array}$ & $\begin{array}{c}-0.62 * * * \\
(-4.12)\end{array}$ \\
\hline Internet access & $\begin{array}{c}0.25 * * * \\
(4.79)\end{array}$ & $\begin{array}{c}0.30 * * * \\
(7.26)\end{array}$ & $\begin{array}{c}0.23 * * * \\
(3.98)\end{array}$ & $\begin{array}{l}0.32 * * * \\
(7.94)\end{array}$ & $\begin{array}{c}0.21 * * * \\
(3.62)\end{array}$ \\
\hline $\begin{array}{l}\text { Living conditions } \\
\text { (rooms/ pers) }\end{array}$ & $\begin{array}{c}23.32 * * * \\
(6.95)\end{array}$ & $\begin{array}{c}23.19 * * * \\
(6.95)\end{array}$ & $\begin{array}{c}20.81 * * * \\
(5.92)\end{array}$ & $\begin{array}{c}24.29 * * * \\
(7.26)\end{array}$ & $\begin{array}{c}23.72 * * * \\
(6.72)\end{array}$ \\
\hline Living cost & $\begin{array}{l}-0.26^{* *} \\
(-2.15)\end{array}$ & $\begin{array}{l}-0.26 * * \\
(-2.15)\end{array}$ & $\begin{array}{l}-0.25 * * \\
(-2.08)\end{array}$ & $\begin{array}{l}-0.28 * * \\
(-2.34)\end{array}$ & $\begin{array}{l}-0.28 * * \\
(-2.36)\end{array}$ \\
\hline Constant & $\begin{array}{l}-14.33^{*} \\
(-1.93)\end{array}$ & $\begin{array}{c}-29.66 * * * \\
(-3.00)\end{array}$ & $\begin{array}{c}-25.04 * * * \\
(-4.71)\end{array}$ & $\begin{array}{c}-19.15 * * * \\
(-3.48)\end{array}$ & $\begin{array}{l}944.5^{*} \\
(1.64)\end{array}$ \\
\hline Random effect & Yes & Yes & Yes & Yes & Yes \\
\hline Wald chi2 & $195.86^{* * *}$ & $189.71 * * *$ & $196.17 * * *$ & $212.14 * * *$ & $231.54 * * *$ \\
\hline R-sq & 0.483 & 0.450 & 0.440 & 0.388 & 0.428 \\
\hline rho & 0.843 & 0.841 & 0.863 & 0.868 & 0.865 \\
\hline Observations & 237 & 237 & 237 & 237 & 237 \\
\hline
\end{tabular}

Note: $*$ represents $\mathrm{p}<0.1, * * \mathrm{p}<0.05, * * * \mathrm{p}<0.01$; values between parentheses represent $\mathrm{z}$-values

Table no. 5: Panel regression model for the dependent variable recycling rate of municipal waste

\begin{tabular}{|c|c|c|c|c|c|}
\hline \multicolumn{6}{|c|}{ Dependent variable: Recycling rate of waste $(\%)$} \\
\hline & Model 6 & Model 7 & Model 8 & Model 9 & Model 10 \\
\hline Education level 0-2 & $\begin{array}{l}-0.23 \\
(-1.57)\end{array}$ & & $\begin{array}{l}-0.33 * * \\
(-2.49)\end{array}$ & & \\
\hline \multicolumn{6}{|l|}{ Education level 3-4 } \\
\hline Education level 5-8 & $\begin{array}{l}0.33^{*} \\
(1.65)\end{array}$ & $\begin{array}{l}0.47 * * \\
(2.54)\end{array}$ & & & \\
\hline Lifelong learning & $\begin{array}{c}-0.61 * * * \\
(-4.04) \\
\end{array}$ & $\begin{array}{c}-0.60 * * * \\
(-3.93)\end{array}$ & $\begin{array}{c}-0.59 * * * \\
(-3.88)\end{array}$ & & \\
\hline Internet access & $\begin{array}{c}0.20^{* * * *} \\
(3.51) \\
\end{array}$ & $\begin{array}{c}0.22 * * * \\
(4.02) \\
\end{array}$ & $\begin{array}{c}0.25 * * * \\
(4.98) \\
\end{array}$ & $\begin{array}{c}0.30 * * * \\
(6.62) \\
\end{array}$ & $\begin{array}{c}0.31 * * * \\
(7.36) \\
\end{array}$ \\
\hline Urbanization & & & & $\begin{array}{l}-0.043 \\
(-0.73) \\
\end{array}$ & \\
\hline $\begin{array}{l}\text { Living conditions } \\
\text { (room/ pers) }\end{array}$ & $\begin{array}{c}23.32 * * * \\
(6.60)\end{array}$ & $\begin{array}{c}21.97 * * * \\
(6.38)\end{array}$ & $\begin{array}{c}25.34 * * * \\
(7.62)\end{array}$ & $\begin{array}{c}22.66^{* * * *} \\
(6.31)\end{array}$ & $\begin{array}{c}22.65 * * * \\
(6.71)\end{array}$ \\
\hline Living cost & $\begin{array}{l}-0.26 * * \\
(-2.17)\end{array}$ & $\begin{array}{l}-0.26 * * \\
(-2.17)\end{array}$ & $\begin{array}{l}-0.27 \\
(-2.32)\end{array}$ & $\begin{array}{l}-0.25^{* *} \\
(-1.97)\end{array}$ & $\begin{array}{c}-0.27 * * \\
(-2.21)\end{array}$ \\
\hline GDPPC & & & & -0.007 & \\
\hline
\end{tabular}




\begin{tabular}{|l|c|c|c|c|c|}
\hline \multicolumn{7}{|c|}{ Dependent variable: Recycling rate of waste (\%) } \\
\hline & Model 6 & Model 7 & Model 8 & Model 9 & Model 10 \\
\hline & & & & $(-0.08)$ & \\
\hline \multirow{2}{*}{ Constant } & $-8.99 * *$ & $-18.67 * * *$ & -5.02 & $-22.37 * * *$ & $-24.76 * * *$ \\
& $(-1.09)$ & $(-3.40)$ & $(-0.64)$ & $(-3.89)$ & $(-4.66)$ \\
\hline Random effect & Yes & Yes & Yes & Yes & Yes \\
\hline Wald chi2 & $226.89 * * *$ & $224.19 * * *$ & $222.37 * * *$ & $188.71 * * *$ & $190.23 * * *$ \\
\hline R-sq & 0.433 & 0.395 & 0.441 & 0.453 & 0.432 \\
\hline rho & 0.862 & 0.876 & 0.858 & 0.818 & 0.857 \\
\hline Observations & 237 & 237 & 237 & 237 & 237 \\
\hline
\end{tabular}

Note: * represents $\mathrm{p}<0.1, * * \mathrm{p}<0.05, * * * \mathrm{p}<0.01$; values between parentheses represent $\mathrm{z}$-values

For the accuracy of the model and in order to eliminate alternative influences, the model has been tested with the help of several control variables. In a first step, we have checked the influence of the control variables on the dependent variable recycling rate of municipal waste in an economy. In table 5, model 9 , there can be observed a first regression having five control variables as independents. The Wald-chi2 value for this model is 190.23, having $\mathrm{p}=0.000$. A significant influence results from this model for the $\beta$ coefficients of the variables internet access $(\beta 5=0.30, z=6.62, p=0.000)$, living conditions $\left(\beta_{7}=22.66, z=6.31\right.$, $\mathrm{p}=0.000)$ and living cost $(\beta 8=-0.25, \mathrm{z}=-1.97, \mathrm{p}=0.049)$. The variables degree of urbanization $\left(\beta_{9}=-0.043, \mathrm{z}=-0.73, \mathrm{p}=0.463\right)$ and gross domestic product per capita $\left(\beta_{6}=-\right.$ 0.007, $\mathrm{z}=-0.08, \mathrm{p}=0.936$ ) didn't have a sufficient significance in order to be considered for the following analysis. Therefore, the panel regression relation has been tested again with three variables and the results can be observed in model 10 (table 5). For model 10, both the Wald-chi2 value of 190.23 and the rho value of 0.857 are higher than those of model 9 , proving a higher accuracy of model 10. Despite this result, the R-sq values decreases from 0.453 in model 9 , to 0.432 in model 10 , showing that the two control variables degree of urbanization and GDPPC have a small non-linear influence on the dependent variable rate of recycling. For model 10, all $\beta$ coefficients are significant and therefore we will have the control variables internet access $\left(\beta_{5}=0.31, \mathrm{z}=7.36, \mathrm{p}=0.000\right)$, living conditions $\left(\beta_{7}=22.65\right.$, $\mathrm{z}=6.71, \mathrm{p}=0.000)$ and living costs $\left(\beta_{8}=-0.27, \mathrm{z}=-2.21, \mathrm{p}=0.027\right)$.

In order to observe the ceteris paribus influence of each of the four independent variables, in models 1-4 we have tested panel regression models with one of the four independent variables for each relation and the three significant control variables. Table 4 , model 1 presents the results of the panel data model having the recycling rate as dependent variable and the percentage of people having only primary and lower secondary education as independent variable and the three control variables. The value Wald-chi $2=195.86$ $(\mathrm{p}=0.000)$ and the value rho=0.843 show a high adequacy of the model. For the independent variable primary education, the coefficient $\beta_{1}=-0.25(\mathrm{p}=0.053)$ is negative, showing an inverse relation between the two variables. Consequently, the higher is the percentage of people having only education level 0-2 according to ISCED, the lower is the recycling rate of municipal waste. In model 1 , the control variables including the constant have similar values to those in model 10 , all of them having $\mathrm{p}<0.055$, proving that the model is robust. An increase of R-sq to 0.483 (in comparison to R-sq=0.432 in model 10) can also be observed, which shows an increase of influence on the dependent variable, 
explained by adding the variable percentage of persons having only primary or lower secondary education.

In model 2, the influence of the variable upper secondary education can be observed, level 3-4 according to ISCED on the recycling rate of waste. Although the values Waldchi $2=189.71(\mathrm{p}=0.000)$ and rho= 0.841 show a high adequacy of the model, the significance of the $\beta$ coefficient of the independent variable is low, having $\mathrm{z}=0.61$ and $\mathrm{p}=0.540$. Both the control variables and the constant have similar values to those of model 10 and they have significant $\beta$ coefficients ( $\mathrm{p}<0.032$ ). The increase of the $\mathrm{R}$-sq value to 0.450 (in comparison to $\mathrm{R}$-sq=0.432 of model 10) shows an influence of this variable, but which is not quantified in this linear model.

Model 3 presents the results of the panel data analysis for the recycling rate and the independent variable tertiary education. The value Wald-chi2 $=196.17(p=0.000)$ and the value rho $=0.863$ show a high adequacy of this model. In the case of the independent variable tertiary education, there is a positive relation with the dependent variable recycling rate of waste, having $\beta_{3}=0.36(\mathrm{z}=1.90$ and $\mathrm{p}=0.057)$. In this case, the $\beta$ coefficient of the control variables and the constant have similar and significant values $(p<0.038)$ too. Consequently, the higher is the number of persons having tertiary education, the higher is the recycling rate. For model 3, there can be observed an increase of the R-sq value to 0.440 , fact that confirms the influence of this variable.

Model 4 presents the impact of the lifelong learning on the recycling rate of municipal waste. In table 4 , it can be observed that Wald-chi2 $=212.14(\mathrm{p}=0.000)$ and rho $=0.868$ have the highest value compared to the models with only one independent variable, proving the significance of the model. In this model all $\beta$ coefficients are significant, including the independent variable, the control variables and the constant, having all $p<0.020$. In spite of this, the value of the coefficient $\beta_{4}=-0.53(\mathrm{z}=-3.48$ and $\mathrm{p}=0.000)$ is negative suggesting that the higher is the rate of people participating in lifelong learning education, the lower is the recycling rate in that economy. There can be also observed that the value $\mathrm{R}-\mathrm{sq}=0.388$ for this model is lower compared to model 10 , where $\mathrm{R}-\mathrm{sq}=0.432$. This shows that the variable has a negative influence on the recycling rate and that it even reduces the influence of the other variables.

In model 5, a panel regression model has been tested with all independent and all three control variables. As it can be observed in table 4, this is a significant model having Waldchi $2=231.54(\mathrm{p}=0.000)$ and rho=0.865, suggesting that the independent variables influence the dependent variable recycling rate. Despite this, the $\beta$ coefficients of the independent variables don't have the best values, which suggests that there are influences among the variables in this relation. Besides, the correlation matrix of the independent variables presented in table 3 , shows a strong negative correlation between the education level $0-2$ and the education level 3-4 ( $\mathrm{r}=-0.837)$, fact that can cancel the influence of the two variables. Between the variables tertiary education and lifelong learning there is also a moderate positive relation ( $\mathrm{r}=0.601)$. The lower value $\mathrm{R}$-sq=0.420 compared to model 10 $(\mathrm{R}-\mathrm{sq}=0.432)$ also suggests that the independent variables cancel each other's influences on the dependent variable.

Taking in consideration the fact that model 5 doesn't have the highest significance, in table $4 \mathrm{~b}$, in models $6-8$, we have tested several combinations of the four independent variables. In model 6, a panel regression with three independent variables is presented, that doesn't 
include the upper secondary level, because of its low significance in models 1-4. This model with three independent variables has the values Wald-chi2 $=226.89(p=0.000)$ and rho $=0.862$. The values of the $\beta$ coefficients are similar to those of the other models, having a high significance for the lifelong learning $\left(\beta_{4}=-0.61, \mathrm{z}=-4.04\right.$ and $\left.\mathrm{p}=0.000\right)$, a moderate significance for the tertiary education $\left(\beta_{3}=-0.61, \mathrm{z}=0.33\right.$ and $\left.\mathrm{p}=0.099\right)$ and a weak significance for the primary and lower secondary education $\left(\beta_{1}=-0.23, \mathrm{z}=-1.57\right.$ and $\mathrm{p}=0.116)$.

The panel regression with independent variables tertiary education and lifelong learning is presented in model 7. This model also has a high level of significance with Wald chi2 $=$ $224.19(\mathrm{p}=0.000), \mathrm{rho}=0.876$, and significant coefficients $\beta$ for both variables $(\mathrm{p}<0.012)$ that keep similar values with those of other models. The lower value of $\mathrm{R}$-sq=0.395 in comparison with that of model 10 can be influenced by the moderate correlation between the two variables. Model 8, with the independent variables level of primary and lower secondary education and lifelong learning, is also significant, with Wald chi2 $=222.37$ $(\mathrm{p}=0.000)$, rho $=0.858$, and significant $\beta$ coefficients for both variables $(\mathrm{p}<0.014)$ that keep similar values with those of the other models. In this case the $\mathrm{R}-\mathrm{sq}=0.441$ is higher, proving the influence of the two variables on the recycling rate.

Based on the analysis of the ten models presented above, we can conclude the following regarding the influence that the population's level of education has on the recycling rate. The part of population with only primary and lower secondary education has a negative influence on the recycling rate, with values of $\beta_{1} \in[-0.33 ;-0.23]$. The lack of upper secondary, post-secondary and tertiary education doesn't offer the population the necessary knowledge in order to become aware of the importance that recycling has for the development of the economy, therefore a high level of this category of population leads implicitly to a decrease of the recycling rate. Taking these into account we can state that hypothesis $\mathrm{Hl}$ has been confirmed. For the upper secondary, post-secondary non-tertiary education, no significant relation could be proven. In fact, including this variable in the panel regression (in model 5) has cancelled the influence of the other variables. Based on these results, we can affirm that hypothesis $\mathrm{H} 2$ regarding the influence that the 3-4 level of education according to ISCED has on the recycling rate is rejected. Results of this modelling prove that a high number of people with university education influences the recycling rate positively, with a $\beta_{3} \in[0.33 ; 0.47]$. Thus, we can affirm that hypothesis $H 3$ is confirmed and that tertiary education positively influences the recycling rate in an economy. In opposition with our expectations, lifelong learning has a negative influence on the recycling rate. The models presented in this article prove the existence of a correlation between the percentage of people that participate to lifelong learning and the recycling rate. This relation is proven to be negative, with negative values for coefficient $\beta_{4} \in[-0.62$; 0.53]. The higher the number of people that engage in lifelong learning, the lower the recycling rate of municipal waste is. Given this result, we can state that hypothesis $\mathrm{H} 4$ is rejected.

\section{Conclusions}

The results of this research demonstrate that the population's level of education has an influence on the recycling rate of municipal waste in an economy. Although a significant integrated model couldn't be proven, that would encompass all levels of education in a 
regression with recycling rate as dependent variable, the influence of different levels of education on this variable could still be demonstrated. As it was expected, in an economy, the lack of education influences the recycling rate negatively. A higher percentage of population with only primary and lower secondary education influences the rate of recycling negatively. This result is also confirmed by a research done by Arbues and Villanua (2016). Also, tertiary education has a positive influence on the recycling rate, fact confirmed also by the studies of Starr and Nicolson (2015) and Lopez-Mosquera, LeraLópez and Sánchez (2016). Both results confirm that education has a relevant role in understanding and becoming aware of the importance of recycling and of the circular economy for the development of a society. An interesting aspect is that while results of the research show that there is a correlation between the recycling rate and lifelong learning, this is however negative.

One of the limitations of the research refers to the choice of the data. A first issue is the data regarding education, which refer to a general type of education, without analyzing its content. By analyzing its content, the education can favor or not the behavior of the population towards recycling. Secondly, relative and not absolute data have been considered in this analysis. On one hand these relative data expressed in percentages allow the comparison between the economies of different countries. On the other hand, they give equal values to variables for countries with different dimensions. Despite, the research has an important contribution to the literature, by pointing out the importance of education for a circular economy and implicitly for the development of the society in general.

Starting from the obtained results, a first recommendation for the development of the circular economy is the increase of the education level of the population in general and the reduction of the number of persons having only primary and lower secondary education. According to the presented results, a decrease of the percentage of population, having only education level 0-2 according to ISCED, will have a positive influence on the recycling rate and on the development of the circular economy. A result we have expected, is the positive relation between the university education and the recycling rate. Starting from this result, a second recommendation is to keep and intensify this trend of increased awareness for the importance of the recycling process among students. This increased awareness among students can have a double effect: both at the level of the recycling behavior of the population having tertiary education and also at the level of political decision-makers, explained by the future positions with decision power for the actual students.

An interesting result is that of the negative relation between the recycling rate and the lifelong learning. In order to change this relation into a positive one, our recommendation is to adapt its content in order to favor the recycling behavior. This change can be also done for other levels of education in order to have a long-time effect. Not less important is a permanent information of the population regarding the economic results obtained from the recycling process. As it has been observed, the control variable internet access has a significant influence on the recycling rate. For this reason, it is important to inform the population through different online and offline means of communication in order to increase the pro-recycling behavior.

Besides all these elements, it is important to develop macroeconomic policies for the facilitation of pro-recycling behavior and for the development of a circular economy. But, of course, it is important to know the role of education in the recycling process and how it can support the development of a circular economy. Furthermore, educators should 
consider a holistic approach, taking into account cognitive, emotional and spiritual aspects related to the environment. From a larger social perspective, an increased education level of the population will have positive effects on the development of the circular economy.

\section{References}

Abbott, A., Nandeibam, S. and O'Shea, L., 2011. Explaining the variation in household recycling rates across the UK. Ecological Economics, 70(11), pp.2214-2223.

Arbués, F. and Villanúa, I., 2016. Determinants of behavior toward selective collection of batteries in Spain. A bivariate probit model. Resources, Conservation and Recycling, 106, pp.1-8.

Aphale, O., Thyberg, K.L. and Tonjes, D.J., 2015. Differences in waste generation, waste composition, and sourceseparation across three waste districts in a New York suburb. Resources, Conservation and Recycling, 99, pp.19-28.

Baltagi, B., 2008. Econometric analysis of panel data. Chichester: John Wiley \& Sons Ltd.

Botetzagias, I., Dima, A.F. and Malesios, C., 2015. Extending the Theory of Planned Behavior in the context of recycling: The role of moral norms and of demographic predictors. Resources, Conservation and Recycling, 95(2), pp.58-67.

Blomsma, F. and Brennan, G., 2017. The emergence of circular economy: a new framing around prolonging resource productivity. Journal of Industrial Ecology, 21(3), pp. 603-614.

Brătianu, C., 2007. Thinking patterns and knowledge dynamics. In: B. Martins \& D. Renyi (Eds.), Proceedings of the 8th European Conference on Knowledge Management. Barcelona, Spain, 6-7 September 2007. Reading, UK: Academic Conferences Ltd.

Brătianu, C., 2013. The triple helix of the organizational knowledge. Management Dynamics in the Knowledge Economy, 1(2), pp.207-220.

Brătucu, G., Palade, A., Madar, A., Neacşu, N.A., Boşcor, D. and Băltescu, C.A., 2017. Competition on the University Educational Services Market in Romania and the Protection of Students' Rights and Interests. Amfiteatru Economic, 19(45), pp.414-431.

Chan, L. and Bishop, B., 2013. A moral basis for recycling: Extending the theory of planned behavior. Journal of Environmental Psychology, 36, pp.96-102.

Chen, M.F. and Tung, P.J., 2010. The moderating effect of perceived lack of facilities on consumers' recycling intentions. Environment and Behavior, 42(6), pp.824-844.

Dabija, D.C., Postelnicu, C., Dinu, V. and Mihaila, A., 2017. Stakeholders' perception of sustainability orientation within a major Romanian University. International Journal of Sustainability in Higher Education, 18(4), pp.533-553.

Dahlen, L. and Lagerkvist, A., 2010. Pay as you throw: Strengths and weaknesses of weight-based billing in household waste collection systems in Sweden. Waste Management, 30(1), pp.23-31.

Dahlen, L., Vukicevic, S., Meijer, J.E. and Lagerkvist, A., 2007. Comparison of different collection systems for sorted household waste in Sweden. Waste Management, 27(10), pp.1298-1305.

European Commission, 2015a. Closing the Loop - An EU Action Plan for the Circular Economy. Communication from the Commission to the European Parliament, the 
Council, the European Economic and Social Committee and the Committee of the Regions No. COM (2015) 614/2. Brussels: European Commission.

European Commission, 2015b. Proposal for a Directive of the European Parliment and the Council, amending Directive 2008/98/EC on waste, COM/2015/0595 final. Brussels: European Commission.

European Commission, 2015c. Proposal for a Directive of the European Parliament and of the Council amending Directive 94/62/EC on packaging and packaging waste, COM/2015/0596 final. Brussels: European Commission.

European Environment Agency, 2016. Circular Economy in Europe: Developing the Knowledge Base. [online] Available at: <http://www.eea.europa.eu/publications/ circular-economy-in-europe > [Accessed 26.12.2017].

European Union. 2017. European Circular Economy Stakeholder Platform. [online] Availabe at: <circulareconomy.europa.eu> [Accessed 26.12.2017]

Eurostat, 2017a. Recycling rate of municipal waste (Code: cei_wm011). [online] Available at: <http://ec.europa.eu/eurostat/tgm/table.do?tab=table\&init=1\&language= en\&pcode=cei_wm011\&plugin $=1>$ [Accessed 23.12.2017].

Eurostat, 2017b. Recycling rates for packaging waste (Code: ten00063). [online] Available at: <http://ec.europa.eu/eurostat/tgm/table.do?tab=table\&init=1\&language=en \& pcode $=$ ten00063\&plugin $=1>$ [Accessed 23.12.2017].

Eurostat, 2017c. Population by educational attainment level, sex and age (\%) - main indicators (Code: edat_lfse_03). [online] Available at: <http://ec.europa.eu/eurostat/ web/products-datasets/-/edat_lfse_03> [Accessed 23.12.2017].

Eurostat, 2017d. Households - level of internet access (Code: isoc_ci_in_h). [online] Available at: <http://appsso.eurostat.ec.europa.eu/nui/show.do?dataset=isoc_ci_in_h\& lang=en> [Accessed 23.12.2017].

Eurostat, 2017e. Distribution of population by degree of urbanisation, dwelling type and income group - EU-SILC survey (Code: ilc_lvho01). [online] Available at: <http://appsso.eurostat.ec.europa.eu/nui/show.do?dataset=ilc_lvho01\&lang=en> [Accessed 23.12.2017].

Eurostat, 2017f. Average number of rooms per person by tenure status and dwelling type from 2003 onwards - EU-SILC survey (Code: ilc_lvho03). [online] Available at: <http://appsso.eurostat.ec.europa.eu/nui/show.do?dataset=ilc_lvho03\&lang=en> [Accessed 23.12.2017].

Eurostat, 2017g. Housing cost overburden rate by age, sex and poverty status - EU-SILC survey (Code: ilc_lvho07a). [online] Available at: <http://appsso.eurostat.ec. europa.eu/nui/show.do?dataset=ilc_lvho07a\&lang=en> [Accessed 23.12.2017].

Eurostat, 2017h. Main GDP aggregates per capita (Code: nama_10_pc). [online] Available at: <http://appsso.eurostat.ec.europa.eu/nui/submitViewTableAction.do> [Accessed 23.12.2017].

Eurostat, 2017i. Participation rate in education and training (last 4 weeks) by sex and age (Code: trng_lfs_01). [online] Available at: <http://appsso.eurostat.ec.europa.eu/ nui/show.do?dataset=trng_lfs_01\&lang=en> [Accessed 23.12.2017]. 
Geissdoerfer, M., Savaget, P., Bocken, N.M.P. and Hultink, E.J., 2017. The circular economy-a new sustainability paradigm? Journal of Cleaner Production, 143(1), pp.757-768.

Gellynck, X., Jacobsen R. and Verhelst, P., 2011. Identifying the key factors in increasing recycling and reducing residual household waste: a case study of the Flemish region of Belgium. Journal of Environmental Management, 92(10), pp.2683-2690.

Jones, N., Evangelinos, K., Halvadakis, C.P., Iosifides, T. and Sophoulis, C.M., 2010. Social factors influencing perceptions and willingness to pay for a market-based policy aiming on solid waste management. Resources, Conservation and Recycling, 54(9), pp.533-540.

Junot, A., Paquet, Y. and Martin-Krumm, C., 2017. Passion for outdoor activities and environmental behaviors: A look at emotions related to passionate activities. Journal of Environmental Psychology, 53, pp.177-184.

Lauren, N., Fielding, K.S., Smith, L. and Louis, W.R., 2016. You did, so you can and you will: Self-efficacy as a mediator of spillover from easy to more difficult proenvironmental behavior. Journal of Environmental Psychology, 48, pp.191-199.

López-Mosquera, N., Lera-López, F. and Sánchez, M., 2015. Key factors to explain recycling, car use and environmentally responsible purchase behaviors: A comparative perspective. Resources, Conservation and Recycling, 99, pp.29-39.

Malinauskaite, J., Jouhara, H., Czajczyńska, D., Stanchev, P., Katsou, E. and Rostkowski, P., 2017. Municipal solid waste management and waste-to-energy in the context of a circular economy and energy recycling in Europe. Energy, 141, pp.2013-2044.

Nguyen, T.N., Lobo, A. and Greenland, S., 2016. Pro-environmental purchase behaviour: The role of consumers' biospheric values. Journal of Retailing and Consumer Services, 33, pp.98-108.

Ntona, E., Arabatzis, G. and Kyriakopoulos, G.L., 2015. Energy saving: Views and attitudes of students in secondary education. Renewable and Sustainable Energy Reviews, 46, pp.1-15.

Oztekin, C., Teksöz, G., Pamuk, S., Sahin, E. and Kilic, D.S., 2017. Gender perspective on the factors predicting recycling behavior: Implications from the theory of planned behavior. Waste Management, 62, pp.290-302.

Reike, D., Vermeulen, W.J.V. and Witjes, S., 2017. The circular economy: New or Refurbished as CE 3.0? - Exploring Controversies in the Conceptualization of the Circular Economy through a Focus on History and Resource Value Retention Options. Resources, Conservation \& Recycling. In Press. [online] Available at: <https://ac.elscdn.com/S0921344917302756/1-s2.0-S0921344917302756-main.pdf?_tid=5ffa0454ec7d-400e-bfc1-e59ce0e56421\&acdnat=1521506018_c4853b57ddaefde7945778b461 b1b46b> [Accessed 23.12.2017].

Saphores, J.D.M. and Nixon, H., 2014. How effective are current household recycling policies? Results from a national survey of U.S. households. Resources, Conservation and Recycling, 92, pp.1-10.

Sidique, S.F., Joshi, S.V. and Lupi, F., 2010a. Factors influencing the rate of recycling: An analysis of Minnesota counties. Resources, Conservation and Recycling, 54(4), pp. 242-249. 
Sidique, S.F., Lupi, F. and Joshi, S.V., 2010b. The effects of behavior and attitudes on dropoff recycling activities. Resources, Conservation and Recycling, 54(3), pp.163-170.

Suttibak, S. and Nitivattananon, V., 2008. Assessment of factors influencing the performance of solid waste recycling programs. Resources, Conservation and Recycling, 53(1-2), pp.45-56.

Starr, J. and Nicolson, C., 2015. Patterns in trash: Factors driving municipal recycling in Massachusetts. Resources, Conservation and Recycling, 99, pp.7-18.

Yakobovitch, N. and Grinstein, A., 2016. Materialism and the boomerang effect of descriptive norm demarketing: Extension and remedy in an environmental context. Journal of Public Policy \& Marketing, 35(1), pp.91-107. 